\title{
Proposed Cool Coatings with High Near-Infrared Reflectance and Heat Insulation for Asphalt Pavement
}

\author{
Kui Hu $(D)$, Yujing Chen *D, Guixiang Chen *D, Yuzhou Duan and Caihua Yu \\ College of Civil Engineering, Henan University of Technology, Zhengzhou 450001, China; \\ mailhukui@haut.edu.cn (K.H.); duanyz@haut.edu.cn (Y.D.); enyue0919@gmail.com (C.Y.) \\ * Correspondence: yujingchen@haut.edu.cn (Y.C.); $\operatorname{cgx} @$ haut.edu.cn (G.C.)
}

Citation: $\mathrm{Hu}, \mathrm{K} . ;$ Chen, Y.; Chen, G.; Duan, Y.; Yu, C. Proposed Cool Coatings with High Near-Infrared Reflectance and Heat Insulation for Asphalt Pavement. Coatings 2021, 11, 85. https://doi.org/10.3390/ coatings11010085

Received: 2 December 2020 Accepted: 8 January 2021 Published: 13 January 2021

Publisher's Note: MDPI stays neutral with regard to jurisdictional clai$\mathrm{ms}$ in published maps and institutional affiliations.

Copyright: (C) 2021 by the authors. Licensee MDPI, Basel, Switzerland. This article is an open access article distributed under the terms and conditions of the Creative Commons Attribution (CC BY) license (https:// creativecommons.org/licenses/by/ $4.0 /)$.

\begin{abstract}
In summer, black asphalt pavement can absorb a considerable amount of solar radiation, which causes its temperature to rise. Heated asphalt pavement can aggravate the urban heat island (UHI) effect and transfer heat downward, which may cause the problem of permafrost thawing beneath pavements. The objective of this study was to develop a novel cool coating layer (CCL) with high near-infrared reflectance and heat insulation to make the surface of asphalt pavement cool. A self-developed test device and method was established to evaluate cooling effects. Based on the experimental results, the optimal coating can cool asphalt pavement by $11.21^{\circ} \mathrm{C}$ when the radiation striking the sample surface is $650 \mathrm{~W} / \mathrm{m}^{2}$. This coating, called the composite cool coating layer (CCCL), is composed of the following materials: polyurethane resin, rutile $\mathrm{TiO}_{2}$ of $18 \%$, hollow glass microspheres of $12 \%$, and copper chromite black spinel of $0.7 \%$. Silicon carbide particles of $1 \mathrm{~kg} / \mathrm{m}^{2}$ can help the CCCL achieve satisfactory antiskid performance. In conclusion, CCCL can effectively inhibit the absorption of solar radiation and reduce the flow of thermal energy downward without sacrificing skid resistance.
\end{abstract}

Keywords: asphalt pavement; permafrost protection; cool coating layer; temperature

\section{Introduction}

Asphalt pavement is widely used in major highways because it has the advantages of offering a smooth and relatively quiet ride and being easy to maintain. However, its solar radiation absorption rate exceeds $90 \%$, causing undesirable heating of the pavement and the soil beneath it. In the high-altitude western regions of China, the annual total solar radiation is as high as $7000-9000 \mathrm{MJ} / \mathrm{m}^{2}, 50 \%$ higher than that in eastern regions of China at the same latitude [1]. Much of this radiant heat is transferred to the soil below the pavement [2-6], which is permafrost. Permafrost thawing beneath highways is therefore a serious problem.

This kind of problem occurs frequently in the high-altitude (about $4500 \mathrm{~m}$ ) western regions of China, including Qinghai Province and Tibet. Figure 1 demonstrates the specific location. In order to alleviate the permafrost-thawing problem beneath highways in these regions, researchers in China and other countries have advocated maintaining low temperatures in the roadbed by burying ventilation pipes, building crushed-rock interlayer embankments, and other measures [7-13], but such measures are very expensive and difficult to implement [14-17]. Some researchers have also advocated inhibiting the transfer of heat by changing the porosity of the asphalt pavement [18-21], but adopting a largeporosity asphalt mixture can cause serious rutting problems in the summer [22,23]. None of these proposed measures do anything to reduce the strong absorption of solar radiation, so they do not prevent the basic problem-heat entering pavements. Presently, a small number of scholars have applied cool coatings to cool asphalt pavement [24-30]. This method is less expensive and can help reduce the temperature of pavement surfaces effectively. It is of great significance for the protection of frozen soil to improve the cooling effect of cool coatings and inhibit the downward transfer of heat. 


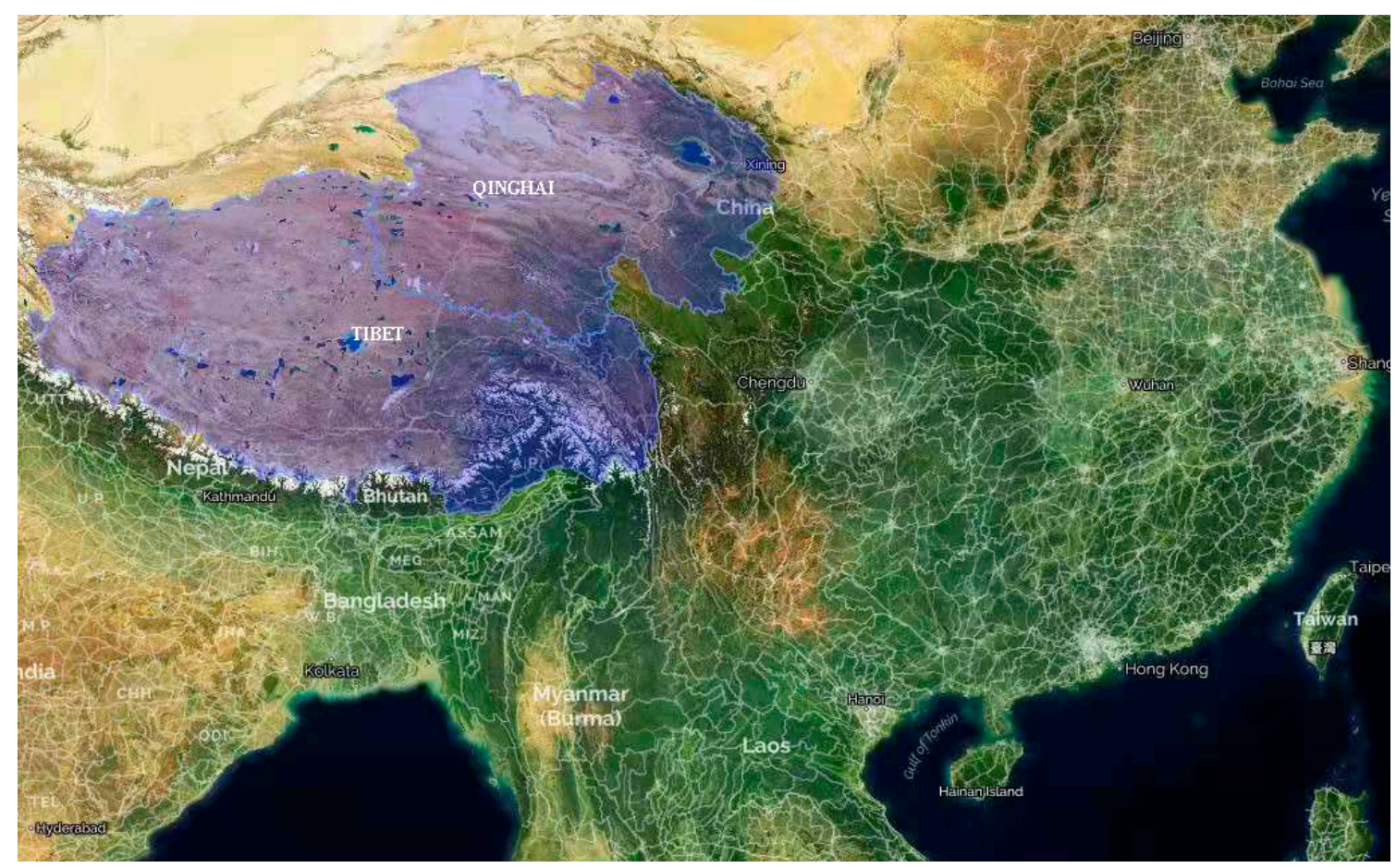

Figure 1. High-altitude western regions of China.

The purpose of this study was to prepare three kinds of cool coating layers (CCLs) with different functions, namely, a reflective cool coating layer (RCCL), an insulative cool coating layer (ICCL), and a composite cool coating layer (CCCL). Firstly, equipment was developed for evaluating the cooling effect of coatings, and scientific methods were also developed based on the actual environmental situation around asphalt pavement to ensure that the measured results are more scientific and accurate. Secondly, the cooling effect of each functional coating was tested by the abovementioned device to determine the optimal coating. Then, the content of functional materials in the optimal coating was determined. Additionally, skid resistance performance on pavements is a key factor and, hence, road administrations must ensure a minimum value in the road network [31-33]. Therefore, finally, the antiskid performance of the optimal coating was improved to ensure that vehicles can drive safely and smoothly after it is applied to asphalt pavement.

\section{Materials and Methods}

\subsection{Design Principles of Cool Coatings}

The environment for asphalt pavement is shown in Figure 2. Most of the total solar radiation is absorbed, thus causing the pavement's temperature to rise. Another way for the pavement to obtain heat is atmospheric counter radiation. The forms of releasing heat outward include reflected radiation, thermal radiation, convective heat transfer with the atmosphere, and heat transfer downward, which harms the permafrost.

The atmosphere releases heat outward in the form of radiation, the direction of which is both upward and downward. The downward part of the atmospheric radiation is just opposite to the direction of ground radiation; that is, atmospheric counter radiation. Its intensity is related to factors such as air temperature and humidity, as shown in Equations (1) and (2):

$$
\begin{gathered}
E_{s k y}=\varepsilon \sigma T_{\text {sky }} \\
T_{s k y}=0.0552 T_{\infty}^{1.5}
\end{gathered}
$$

where $E_{s k y}$ denotes atmospheric counter radiation $\left(\mathrm{W} / \mathrm{m}^{2}\right), \varepsilon$ denotes atmospheric emissivity, $\sigma$ denotes the Stefan-Boltzmann constant as $5.67 \times 10^{-8}\left(\mathrm{~W} /\left(\mathrm{m}^{2} \cdot \mathrm{K}^{4}\right)\right), T_{s k y}$ denotes 
the sky effective temperature $(\mathrm{K})$, and $T_{\infty}$ denotes the atmospheric thermodynamic temperature (K).

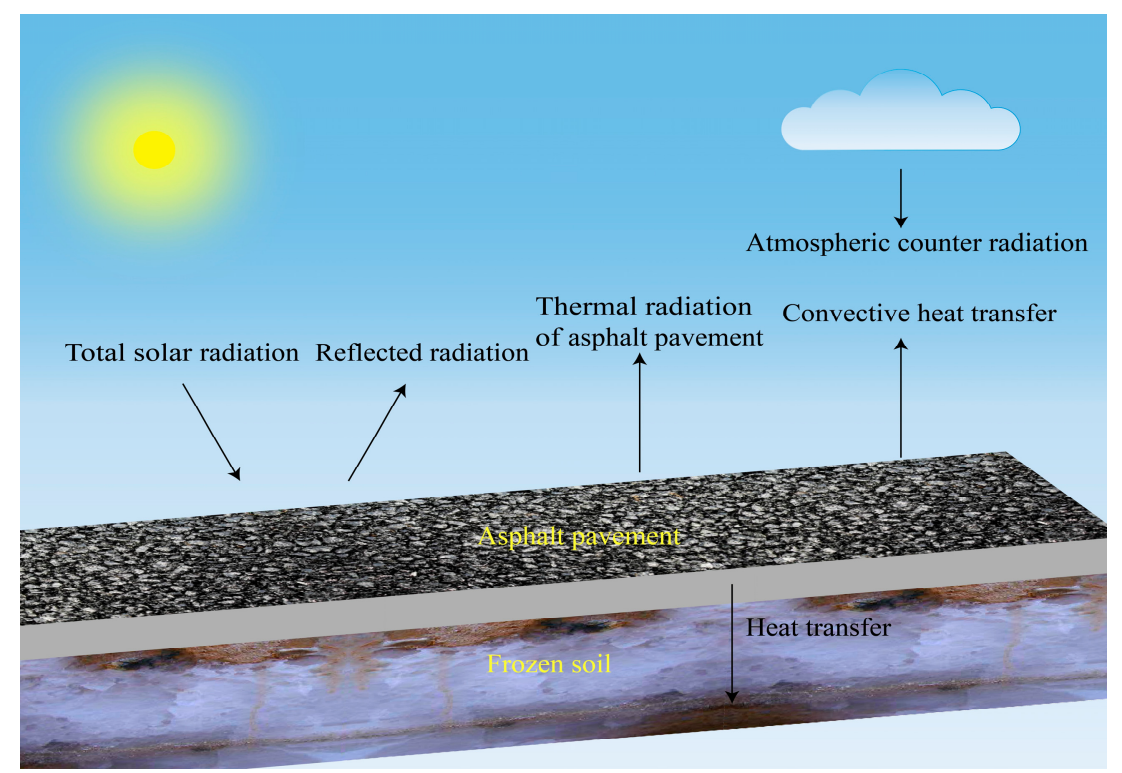

Figure 2. The environment for asphalt pavement.

Asphalt pavement can release internal heat in several ways. Firstly, radiation is one way to reduce its own heat and its wavelength is mainly 1-30 $\mu \mathrm{m}$, which belongs to longwave radiation. The level of its radiation capacity is closely related to the temperature of the pavement surface, as shown in Equation (3):

$$
E_{\text {sur }}=\varepsilon \sigma T_{\text {sur }}^{4}
$$

where $E_{\text {sur }}$ denotes thermal radiation of asphalt pavement, $\varepsilon$ denotes emissivity of asphalt pavement, $\sigma$ denotes the Stefan-Boltzmann constant as $5.67 \times 10^{-8}\left(\mathrm{~W} /\left(\mathrm{m}^{2} \cdot \mathrm{K}^{4}\right)\right)$, and $T_{\text {sur }}$ denotes the surface temperature of asphalt pavement.

Second, it exchanges heat with the atmosphere through convective heat exchange, which is closely related to atmospheric temperature. Moreover, the wind can increase the intensity of convective heat transfer, so that the pavement surface loses heat as soon as possible, as shown in Equation (4):

$$
q_{h}^{\prime}=h\left(T_{\text {sur }}-T_{\infty}\right)
$$

where $q_{h}^{\prime}$ denotes the specific rate of convective heat transfer $\left(\mathrm{W} / \mathrm{m}^{2}\right), h$ denotes the convective heat transfer coefficient, $T_{\text {sur }}$ denotes the surface temperature of asphalt pavement, and $T_{\infty}$ denotes the fluid temperature.

The heat flow equation of asphalt pavement is as follows:

$$
q^{\prime}=\alpha\left(G_{S}+G_{s k y}\right)-G_{s u r}-G_{h}
$$

where $q^{\prime}$ denotes the specific rate of heat flow $\left(\mathrm{W} / \mathrm{m}^{2}\right), \alpha$ denotes absorptivity of total solar radiation, $G_{S}$ denotes total solar radiation $\left(\mathrm{W} / \mathrm{m}^{2}\right), G_{s k y}$ denotes atmospheric counter radiation $\left(\mathrm{W} / \mathrm{m}^{2}, G_{\text {sky }}=E_{\text {sky }}\right), G_{\text {sur }}$ denotes thermal radiation $\left(\mathrm{W} / \mathrm{m}^{2}, G_{\text {sur }}=E_{\text {sur }}\right)$, and $G_{h}$ denotes convective heat transfer $\left(\mathrm{W} / \mathrm{m}^{2}, G_{h}=q_{h}^{\prime}\right)$.

When $q^{\prime}=0$, the asphalt pavement is in thermal equilibrium, as shown in Equation (6):

$$
\alpha\left(G_{S}+G_{s k y}\right)-G_{s u r}+G_{h}=0
$$


Compared with solar radiation, other environmental factors have little effect on pavement temperature, and they also have a certain relationship with solar radiation [34]. However, the intensity of solar radiation is an uncontrollable factor, so weakening the influence of solar radiation is the fundamental way to reduce the increase in temperature. Therefore, it is possible to increase the reflectivity of asphalt pavement for solar radiation and to reduce the heat transfer into the asphalt pavement. In this way, it is likely for asphalt pavement to reduce the temperature in a thermal equilibrium state.

\subsection{Materials}

\subsubsection{Raw Materials}

According to the above design principle, the function of the cool coating is mainly realized by reflective materials and heat-insulating materials. It is necessary for cool coatings to contain other auxiliary materials, such as binding materials, tinting pigments, and additives. Rutile $\mathrm{TiO}_{2}$ has a high refractive index, which can effectively reflect the visible and infrared wavelengths of sunlight and inhibit the heat entering the pavement, so it was selected as a kind of reflective material. Its technical indicators are shown in Table 1 . Hollow glass microspheres were used as heat-insulating materials because they have low thermal conductivity $(0.0519 \mathrm{~W} /(\mathrm{m} \cdot \mathrm{K}))$, as shown in Table 2. Polyurethane resin, polymerized by isocyanate (monomer) and a hydroxyl compound, has good bonding performance, antiaging performance, and toughness, and its technical indicators are shown in Table 3, so it was chosen as the bonding material. Copper chromite black spinel has a strong coloring ability, so it was selected as a toning pigment to prevent surface glare. Further, disperse lubricants and curing agents were selected as additives to facilitate the formation of coatings.

Table 1. The technical characteristics of rutile $\mathrm{TiO}_{2}$.

\begin{tabular}{cccccc}
\hline Appearance & Density & $\begin{array}{c}\text { Hardness, } \\
\text { Mohs }\end{array}$ & pH & $\begin{array}{c}\text { Refractive } \\
\text { Index }\end{array}$ & $\begin{array}{c}\text { Thermal } \\
\text { Conductivity }\end{array}$ \\
\hline White & $4.23 \mathrm{~g} / \mathrm{cc}$ & 6.2 & $6.5-8.5$ & 2.8 & $7.4 \mathrm{~W} /(\mathrm{m} \cdot \mathrm{K})$ \\
\hline
\end{tabular}

Table 2. The technical characteristics of hollow glass microspheres.

\begin{tabular}{cccccc}
\hline Appearance & Density & $\begin{array}{c}\text { Compressive } \\
\text { Strength }\end{array}$ & $\begin{array}{c}\text { Thermal } \\
\text { Conductivity }\end{array}$ & pH & $\begin{array}{c}\text { Softening } \\
\text { Point }\end{array}$ \\
\hline White & $0.170 \mathrm{~g} / \mathrm{cc}$ & $8.48 \mathrm{MPa}$ & $0.0519 \mathrm{~W} /(\mathrm{m} \cdot \mathrm{K})$ & 7.2 & $980{ }^{\circ} \mathrm{C}$ \\
\hline
\end{tabular}

Table 3. The technical characteristics of copper chromite black spinel.

\begin{tabular}{cccccc}
\hline Appearance & $\begin{array}{c}\text { Molecular } \\
\text { Formula }\end{array}$ & $\begin{array}{c}\text { Heat } \\
\text { Resistance }\end{array}$ & $\mathbf{p H}$ & Density & $\begin{array}{c}\text { Oil Absorption } \\
\text { Value }\end{array}$ \\
\hline Black & $\mathrm{Cr}_{2} \mathrm{CuO}_{4}$ & $>500{ }^{\circ} \mathrm{C}$ & $6-9$ & $5.3-5.6 \mathrm{~g} \cdot \mathrm{cm}^{-3}$ & $11-23 \mathrm{~g} / 100 \mathrm{~g})$ \\
\hline
\end{tabular}

\subsubsection{Preparation of Samples}

It is necessary to organize the experimental procedures scientifically and to measure the test materials accurately. To ensure the uniformity and stability of the CCL, stirrers and other devices were used. The specific preparation process is shown in Figure 3 [35].

1. Treating the polyurethane resin. It is necessary to add disperse lubricants to reduce the viscosity of the resin and to facilitate the later addition of other functional materials and auxiliary materials. In addition, it is essential to add a defoamer agent to reduce the number of bubbles generated during the later stirring process, thereby fundamentally improving the stability and durability of coatings.

2. Other materials were added, including hollow glass microspheres, rutile $\mathrm{TiO}_{2}$, copper chromite black spinel, and so forth, and then the coating was initially formed. 
3. Treating the above coatings. To make the coating more uniform and stable, an agitator and ultrasonic disperser were used.

4. Spraying. Coatings were sprayed on the surface of the standard rutting board. The rutting board was composed of AC-16 asphalt concrete and its size was $300 \mathrm{~mm} \times$ $300 \mathrm{~mm} \times 50 \mathrm{~mm}$.

5. Curing. In this step, the strength of the coatings continued to increase. The curing speed is closely related to factors such as liquid temperature.

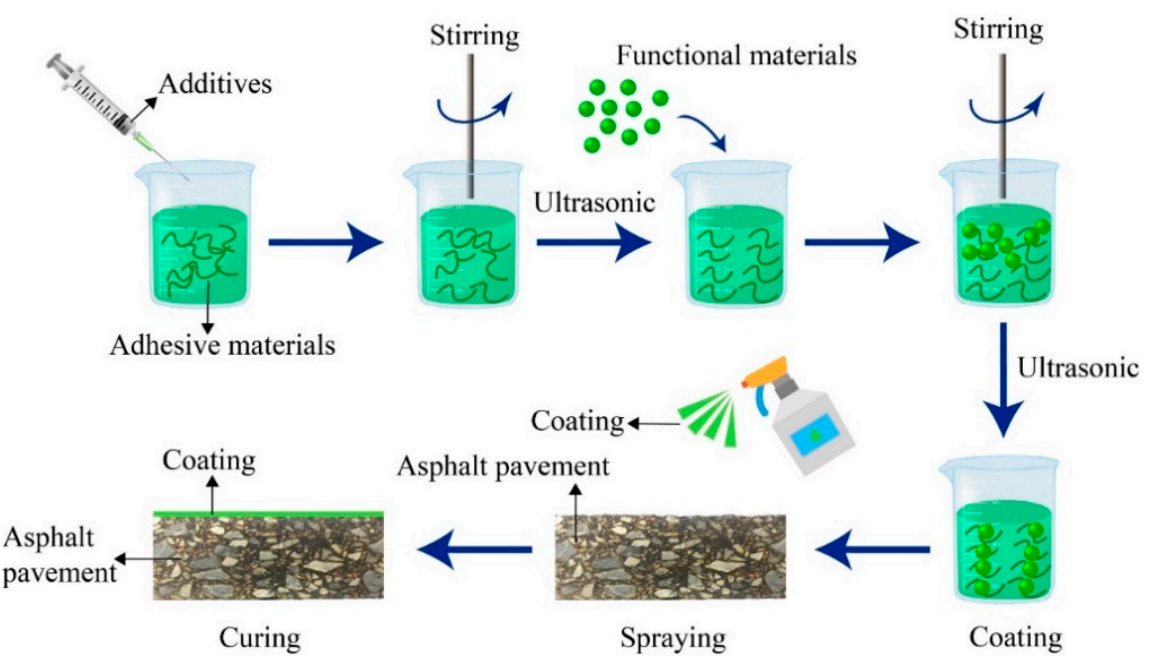

Figure 3. A schematic diagram of the coatings' preparation process.

\subsection{Methods}

A new test device was designed to evaluate the cooling effect of cool coatings under certain environmental conditions, as shown in Figure 4. In order to ensure that the test process is more realistic and scientific, the test device was designed as follows:

- Control of temperature and humidity. The temperature of the test device could be adjusted within the range of $0-30{ }^{\circ} \mathrm{C}$. Figure 5 shows the monthly average temperature in 2019 and August ranked the highest, so that month had the greatest impact on permafrost beneath the pavement. Therefore, the air temperature in August was taken as the reference in the experimental design. Figure 6 shows the daily maximum temperature in this month, ranging from 9 to $17^{\circ} \mathrm{C}$. In order to enable the device to simulate various temperature conditions in August, the temperature range was set to $0-30{ }^{\circ} \mathrm{C}$, which covers the potential change of the temperature range. Humidity was displayed in "real-time." Before starting the test, the temperature and humidity would be adjusted to the required values, which could eliminate the influence of variable factors.

- The rationality of the lighting design. Bromine tungsten lamps were used because their spectrum is similar to that of sunlight, and the unique lampshade allows the light to emit parallel light.

- Arbitrary adjustment of radiation intensity. The power of the lamp was adjusted, the radiation intensity received on the sample surface was monitored by a weather station, and finally, the environmental conditions were achieved that met the test requirements.

- Insulation of samples. The heat loss of samples has a negative effect on the accuracy of the final values. Therefore, the sides and bottom of the samples were covered with insulation material, which was composed of $5 \mathrm{~cm}$ of insulation cotton.

- Accuracy of statistical results. Temperature sensors were placed on the surface of samples, and then they were sealed with thermal silica gel. In the same test, the temperature was measured five times and the average value was used as the final value. 


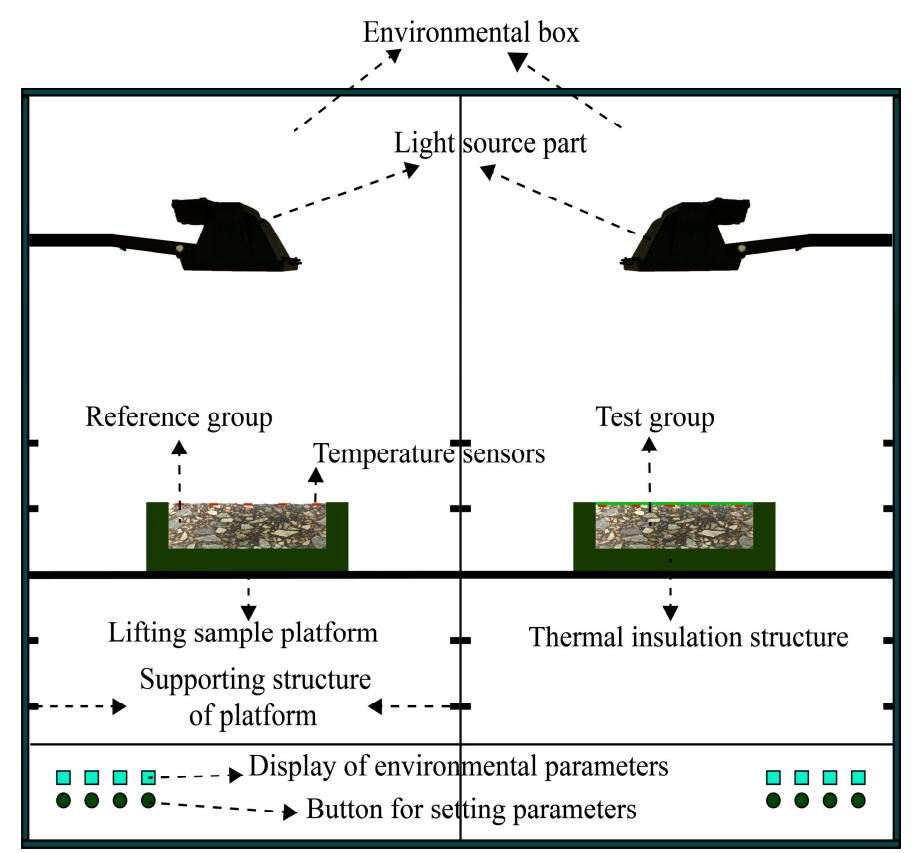

Figure 4. Test of CCL's cooling effect.

The main steps to evaluate the CCL's cooling effects were as follows:

- $\quad$ Establish the parameters. The radiation striking the specimen surface was set equal to the required solar radiation of $650 \mathrm{~W} / \mathrm{m}^{2}$. The temperature in the device was set to $15{ }^{\circ} \mathrm{C}$ and the humidity to $50 \%$. Figure 7 demonstrates the process of setting parameters by different buttons.

- $\quad$ The test device was turned on to make coated and uncoated samples enter the heating stage, so as to measure the cooling effect of the coatings. The cooling effect $\Delta T$ was calculated using Equation (7), where the temperatures were measured every 5 min at the surface of the samples:

$$
\Delta T=\text { Temperature }_{\text {uncoated }}-\text { Temperature }_{\text {coated }}
$$

- Turn off the test device. When the temperature of the samples remained steady, the light was turned off, and then the temperature data were copied to complete the test step.

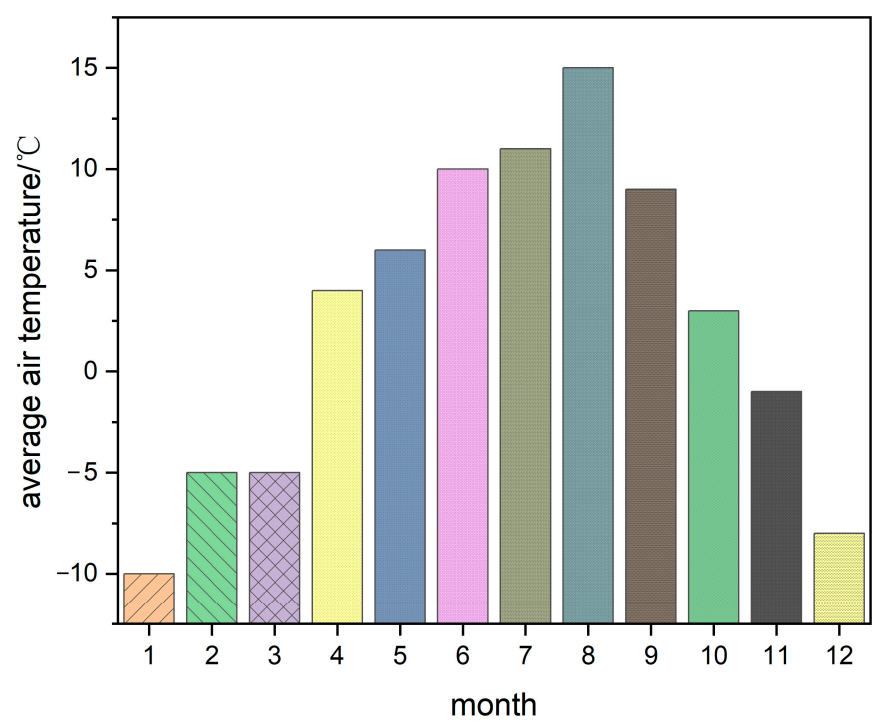

Figure 5. Average air temperature $\left({ }^{\circ} \mathrm{C}\right)$ in every month of 2019. 


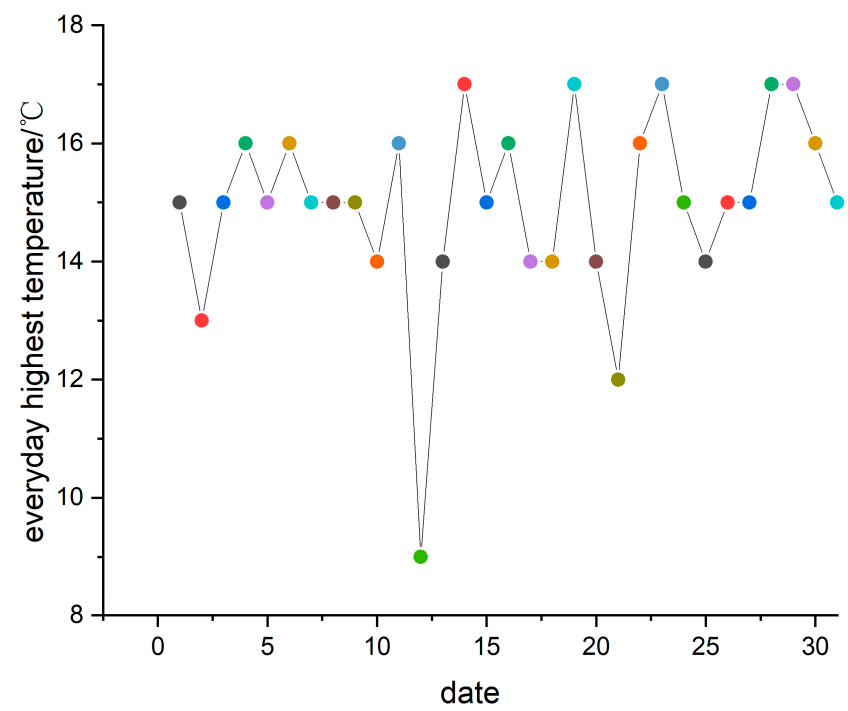

Figure 6. Everyday highest temperature $\left({ }^{\circ} \mathrm{C}\right)$ in August.

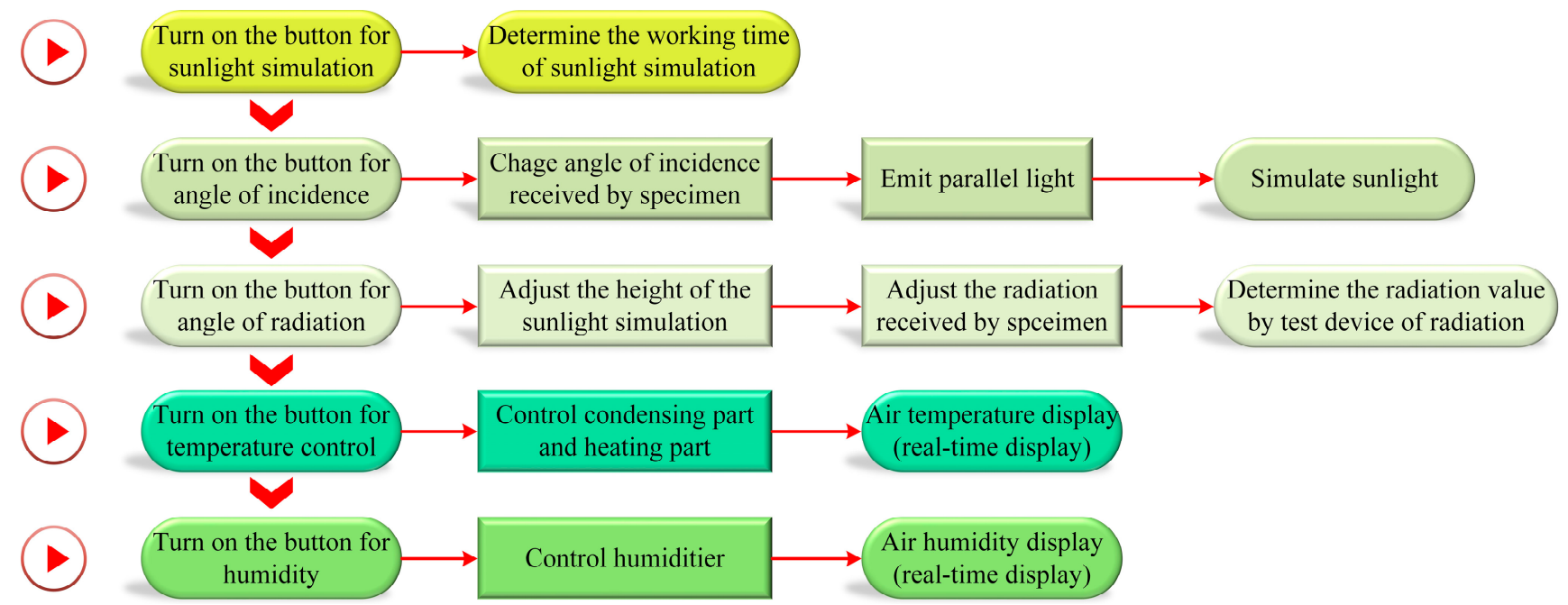

Figure 7. The process of setting parameters.

\section{Results and Discussion}

3.1. Cooling Performance

3.1.1. Effect of Functional Materials on Cooling Performance

The purpose of this test was to clarify the cooling effect of different functional coatings. With the type of functional material as a variable, compositions 1-3 were compared under the same environmental conditions. Among them, composition 1 represents a coating with a heat insulation function, composition 2 represents a coating with a reflection function, and composition 3 represents a composite coating with both heat insulation and reflection functions. The schematic diagram of the coating composition materials is shown in Figure 8. Table 4 demonstrates the composition of the CCLs. The self-developed test device was used to evaluate the cooling effect of each coating, and the test results are shown in Figure 9. 
(a)

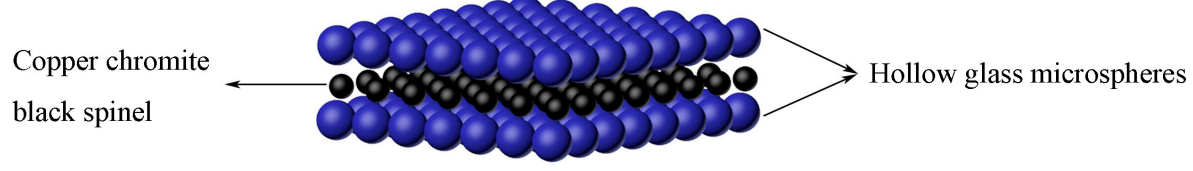

(b)

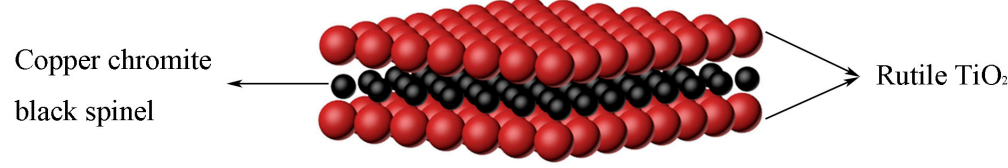

(c)

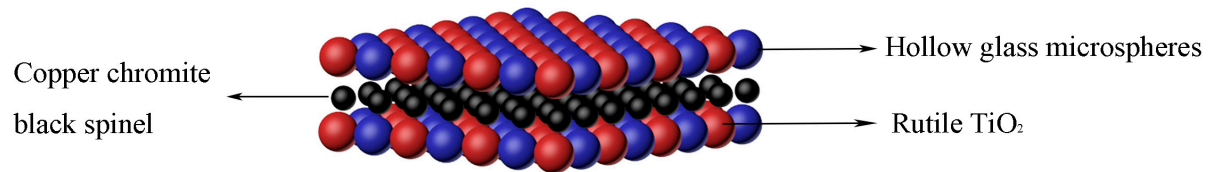

Figure 8. A schematic diagram of CCLs: (a) composition 1 (ICCL); (b) composition 2 (RCCL); (c) composition 3 (CCCL).

Table 4. The composition of CCLs.

\begin{tabular}{ccc}
\hline ICCL & Composition 1 & $\begin{array}{c}\text { Hollow glass microspheres of } 18 \% \text { (VC) } \\
\text { Copper chromite black spinel of } 0.7 \% \text { (mass fraction) }\end{array}$ \\
\hline RCCL & Composition 2 & $\begin{array}{c}\text { Rutile } \mathrm{TiO}_{2} \text { of } 18 \%(\mathrm{VC}) \\
\text { Copper chromite black spinel of } 0.7 \% \text { (mass fraction) }\end{array}$ \\
\hline CCCL & Composition 3 & $\begin{array}{c}\text { Rutile } \mathrm{TiO}_{2} \text { of } 18 \%(\mathrm{VC}) \\
\text { Copper chromite black spinel of } 0.7 \% \text { (mass fraction) } \\
\text { Hollow glass microspheres of } 18 \% \text { (VC) }\end{array}$ \\
\hline
\end{tabular}

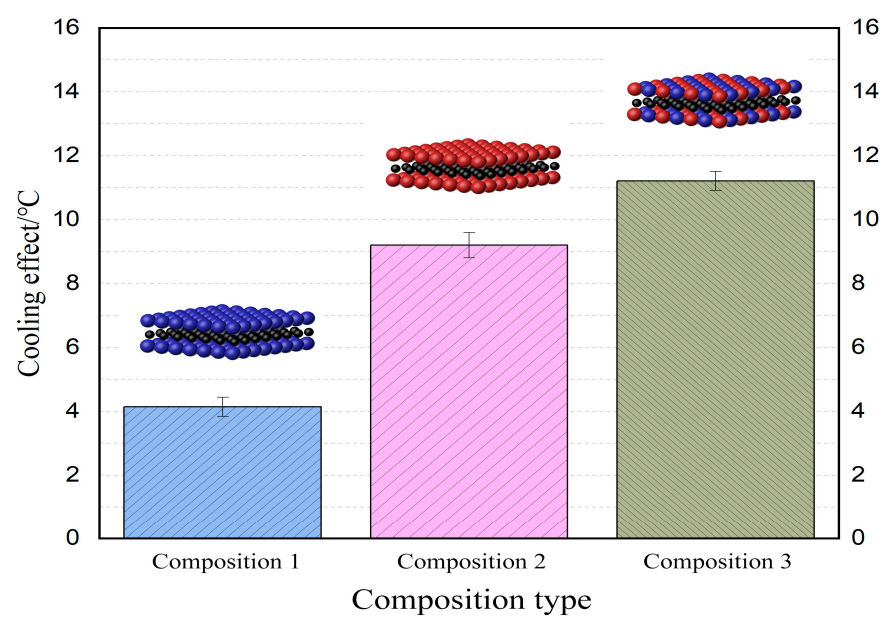

Figure 9. Cooling effect $\left({ }^{\circ} \mathrm{C}\right)$ of CCLs.

There were two stages to the test: the heating phase and the temperature stabilization phase. In the first stage, the uncoated rutting board heated up the fastest, mainly because the black asphalt concrete absorbed most of the radiation, so the temperature rose the fastest. RCCL and CCCL, which contained reflective functional materials, had slower heating rates, meaning that these two coatings could effectively reflect radiation into the air, thereby preventing heat from entering the sample. The ICCL's heating rate was second to the uncoated rutting board, which meant its cooling effect was less than that of the other two cool coatings. In the second stage, there was a stable stage for the temperature of the reference group and the experimental groups, meaning that all groups had entered a state of thermal equilibrium. The difference in the cooling effect of the different compositions was roughly the same as that of the first stage. 
Compared with the uncoated rutting board, the cooling effects of composition 1 , composition 2, and composition 3 were 4.14, 9.2, and 11.21, respectively. The cooling effect of composition 2 was $5.06{ }^{\circ} \mathrm{C}$ greater than that of composition 1 , which indicates that the reflection coefficient is the fundamental factor affecting the surface temperature. The band gap width of the reflective rutile $\mathrm{TiO}_{2}$ phase was $3.0 \mathrm{eV}$, and the refractive index was as high as 2.8. It had high reflectivity to sunlight, especially near-infrared light $(780-1100 \mathrm{~nm})$, as shown in Figure 10. Therefore, rutile $\mathrm{TiO}_{2}$ can be used as a representative material with a reflective function. Composition 3 had the best cooling performance, and its cooling effect reached $11.21{ }^{\circ} \mathrm{C}$. This shows that composition 3 not only has high reflectivity but also can effectively suppress heat transfer downward, which is mainly due to the very low heat transfer efficiency of the hollow glass microspheres of $0.0519 \mathrm{~W} /(\mathrm{m} \cdot \mathrm{K})$.

In summary, the composite coating CCCL had the best cooling effect. It not only had higher infrared reflectivity but also a good heat insulation function.

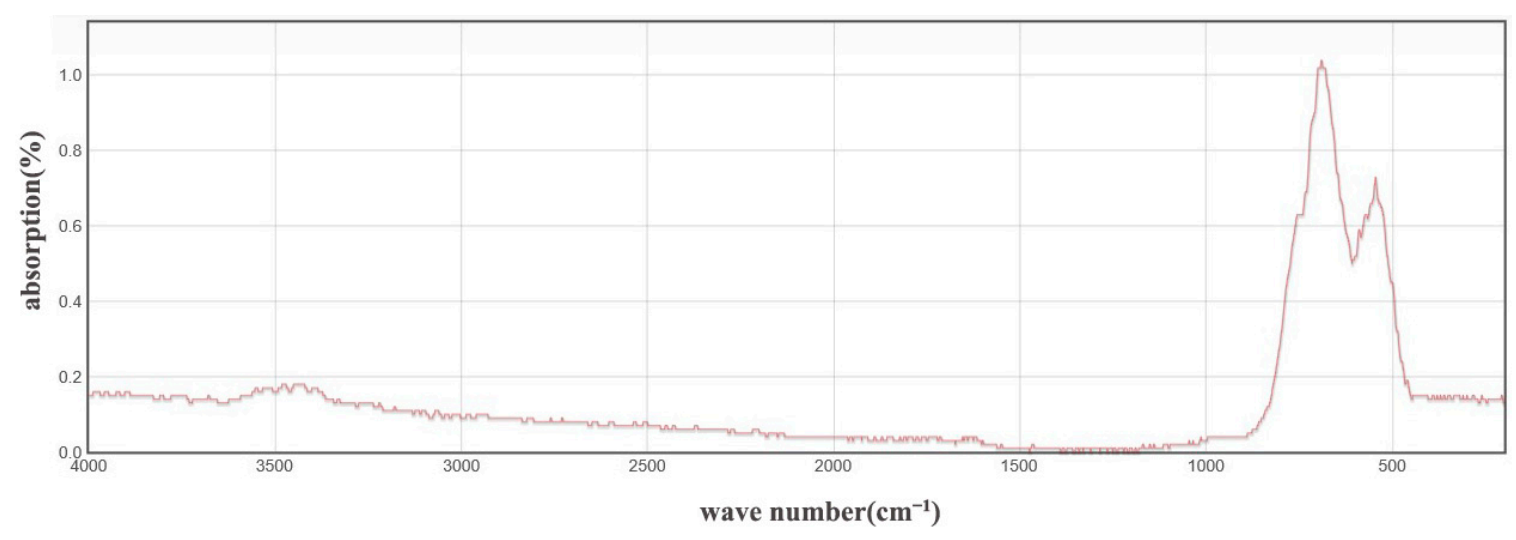

Figure 10. The absorbance spectrum of rutile $\mathrm{TiO}_{2}$.

\subsubsection{Content of Rutile $\mathrm{TiO}_{2}$ in CCCL}

The purpose of this test was to determine the optimal content of rutile $\mathrm{TiO}_{2}$. The experimental groups with different $\mathrm{TiO}_{2}$ contents were compared under the same environmental conditions, as shown in Table 5. A self-made test device was used to test the cooling effect of different coatings, and the test results are shown in Figure 11.

Table 5. CCCLs containing different contents of rutile $\mathrm{TiO}_{2}$.

\begin{tabular}{cc}
\hline Coating Number & Composition \\
\hline \multirow{2}{*}{ Coating 1} & Rutile $\mathrm{TiO}_{2}$ of $0 \%(\mathrm{VC})$ \\
& Copper chromite black spinel of $0.7 \%$ (mass fraction) \\
Hollow glass microspheres of $18 \%$ (VC)
\end{tabular}

The relationship between the cooling effect of CCCL and the content of $\mathrm{TiO}_{2}$ was shown as follows: the cooling effect increased first and then slightly decreased with the increase of the content of $\mathrm{TiO}_{2}$. When the content of $\mathrm{TiO}_{2}$ increased from $0 \%$ to $18 \%$, the 
cooling effect was significantly improved, reaching $11.21^{\circ} \mathrm{C}$. This is mainly because the coating can reflect more visible light and near-infrared light due to the increase in the number of $\mathrm{TiO}_{2}$ particles, thereby reducing heat absorption. However, when the content of $\mathrm{TiO}_{2}$ particles continued to increase to $24 \%$, the cooling effect of CCCL slightly decreased. Meanwhile, the material particles aggregated, which reduced the specific surface area for heat dissipation and reduced the scattering efficiency so that the cooling effect of the CCCL began to decline.

In summary, the optimal content of rutile $\mathrm{TiO}_{2}$ is recommended to be $18 \%$. In this way, the reflective functional particles can be uniformly distributed in the coating without agglomeration, and the best reflective effect is achieved.

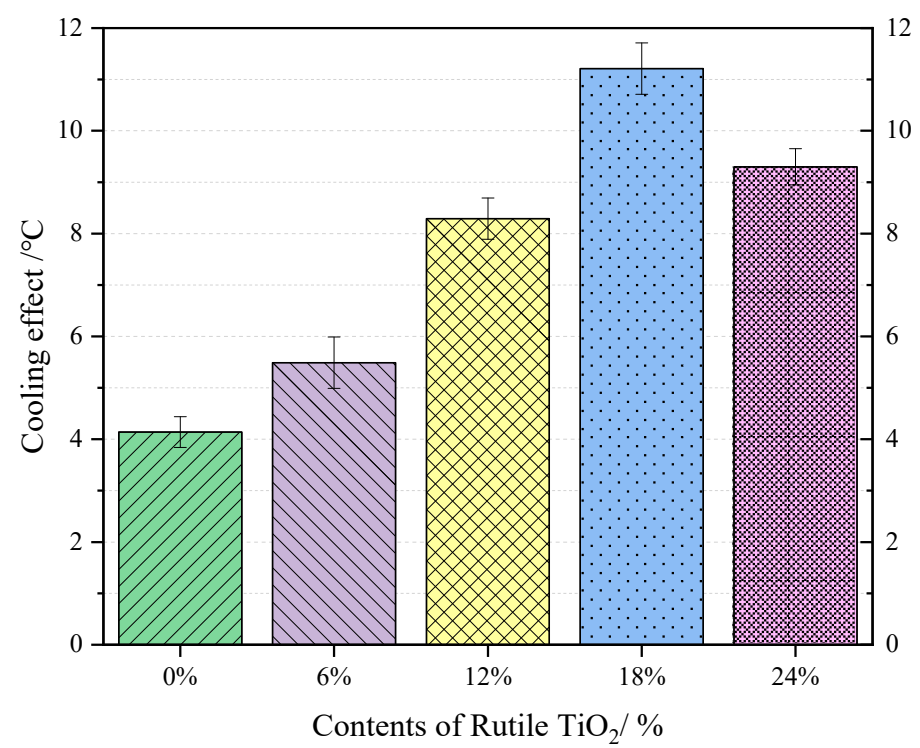

Figure 11. The impact of the contents of rutile $\mathrm{TiO}_{2}$ on the cooling effect.

\subsubsection{Content of Hollow Glass Microspheres in CCCL}

The purpose of this test was to determine the optimal content of hollow glass microspheres. The cooling effects of CCCL with different contents of hollow glass microspheres were compared under the same environmental conditions such as temperature and radiation intensity. The material composition is shown in Table 6. A self-made test device was used to analyze CCCLs' cooling effect.

Table 6. CCCLs containing different contents of hollow glass microspheres.

\begin{tabular}{|c|c|}
\hline Coating Number & Composition \\
\hline Coating 6 & $\begin{array}{c}\text { Hollow glass microspheres of } 0 \%(\mathrm{VC}) \\
\text { Copper chromite black spinel of } 0.7 \% \text { (mass fraction) } \\
\text { Rutile } \mathrm{TiO}_{2} \text { of } 18 \%\end{array}$ \\
\hline Coating 7 & $\begin{array}{c}\text { Hollow glass microspheres of } 6 \%(\mathrm{VC}) \\
\text { Copper chromite black spinel of } 0.7 \% \text { (mass fraction) } \\
\text { Rutile } \mathrm{TiO}_{2} \text { of } 18 \%\end{array}$ \\
\hline Coating 8 & $\begin{array}{c}\text { Hollow glass microspheres of } 12 \%(\mathrm{VC}) \\
\text { Copper chromite black spinel of } 0.7 \% \text { (mass fraction) } \\
\text { Rutile } \mathrm{TiO}_{2} \text { of } 18 \%\end{array}$ \\
\hline Coating 9 & $\begin{array}{c}\text { Hollow glass microspheres of } 18 \% \text { (VC) } \\
\text { Copper chromite black spinel of } 0.7 \% \text { (mass fraction) } \\
\text { Rutile } \mathrm{TiO}_{2} \text { of } 18 \%\end{array}$ \\
\hline Coating 10 & $\begin{array}{c}\text { Hollow glass microspheres of } 24 \% \text { (VC) } \\
\text { Copper chromite black spinel of } 0.7 \% \text { (mass fraction) } \\
\text { Rutile } \mathrm{TiO}_{2} \text { of } 18 \%\end{array}$ \\
\hline
\end{tabular}


The test results are shown in Figure 12. The relationship between CCCL and the content of hollow glass microspheres is expressed as follows: as the content of hollow glass microspheres increased, there was an increasing tendency for the CCCL's cooling effect firstly, which then remained stable. There were five groups of hollow glass microspheres: $0 \%, 6 \%, 12 \%, 18 \%$, and $24 \%$. The peak of the cooling effect of CCCL was $11.21^{\circ} \mathrm{C}$, which was an increase of $2.01{ }^{\circ} \mathrm{C}$ compared with the coating that did not contain hollow glass microspheres. This is because the hollow glass microspheres were evenly distributed in the coating and formed a compact thermal buffer layer, thereby inhibiting the downward transfer of heat. When the content of hollow glass microspheres increased from $12 \%$ to $24 \%$, the cooling effect of the coating hardly changed. However, the material cost and construction cost of the coating could be higher, thereby increasing unnecessary expenditure.

In summary, considering the cooling effect of the coating, the cost expenditure, and ease of construction, $12 \%$ hollow glass microspheres are recommended for use in cool coatings, which is cost-effective.

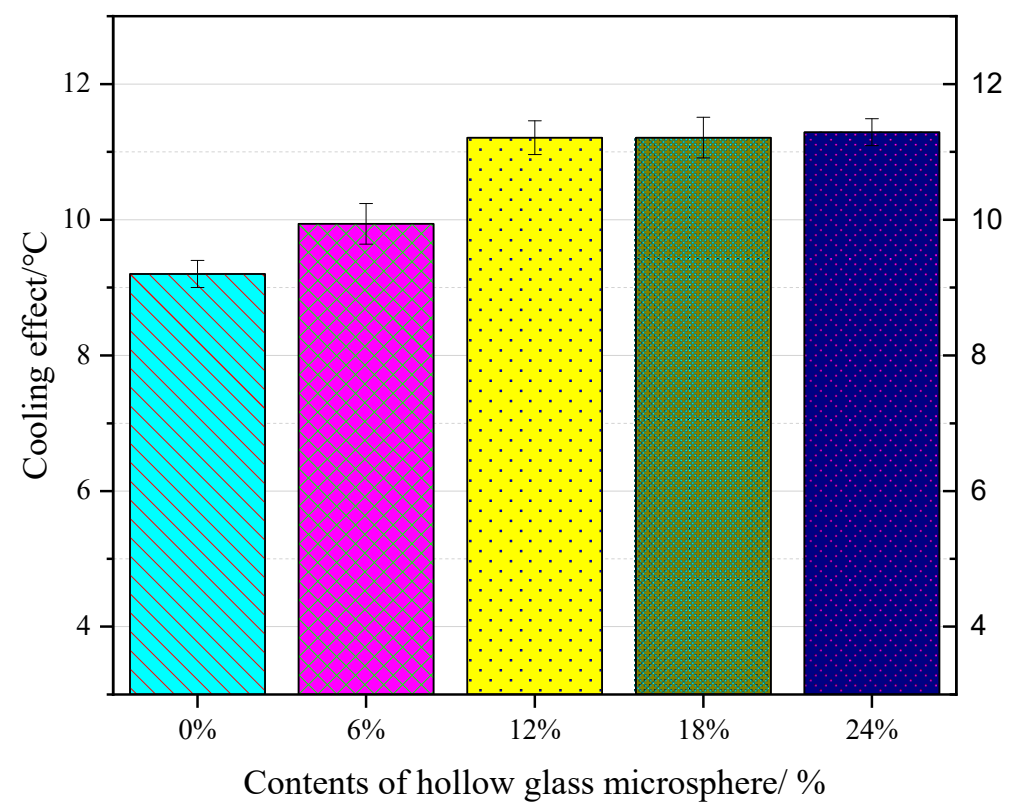

Figure 12. The cooling effect for samples with different contents of hollow glass microspheres.

\subsection{Skid Resistance}

In order to enable vehicles to safely travel on coated asphalt roads, it is essential to study the CCCL's antiskid performance. Silicon carbide particles were used to improve the antiskid performance of the coating. In the experimental groups, each coating contained different contents of silicon carbide- $0,0.5,1$, and $1.5 \mathrm{~kg} / \mathrm{m}^{2}$-as shown in Figure 13 . The reference group was the rutting board without coating. The British Pendulum Number (BPN) method was used to test the BPN of the sample surface so as to meet the antiskid performance requirements of Chinese code [36]. The test results are shown in Figure 14. 

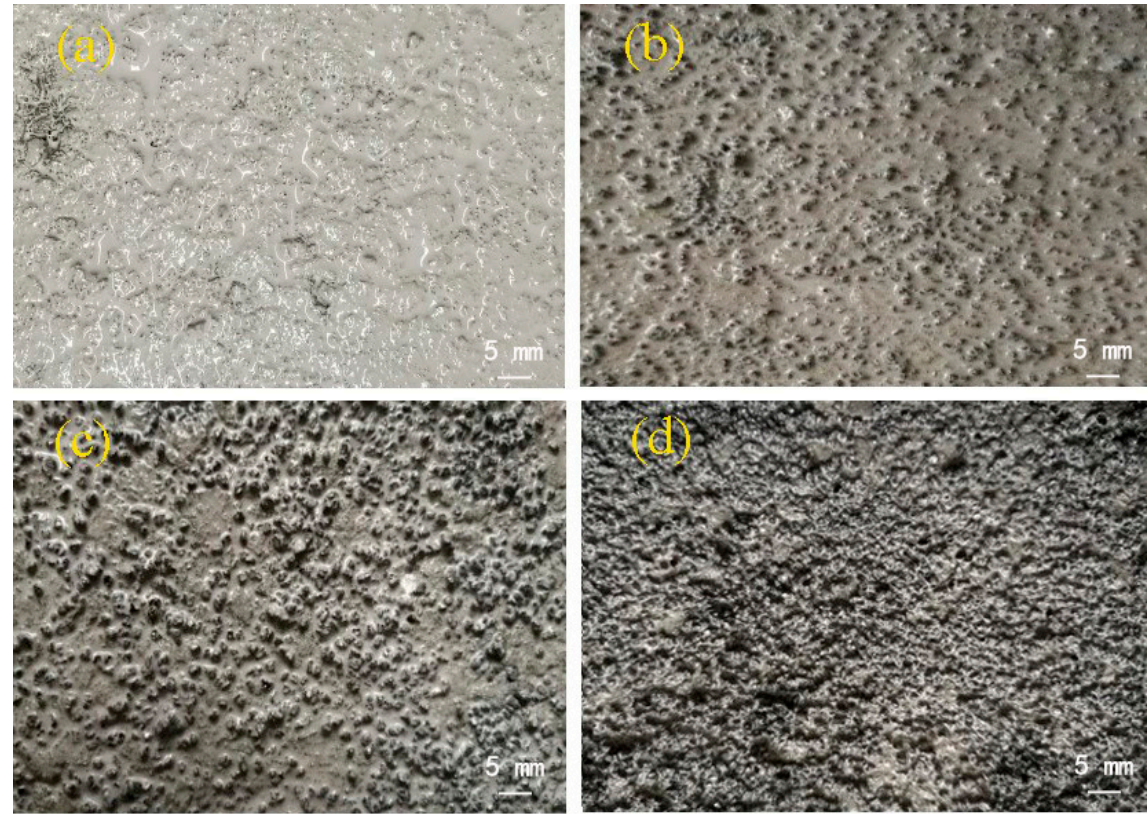

Figure 13. Surface appearance of CCCLs with differing amounts of silicon carbide particles: (a) $0 \mathrm{~kg} / \mathrm{m}^{2}$; (b) $0.5 \mathrm{~kg} / \mathrm{m}^{2}$; (c) $1 \mathrm{~kg} / \mathrm{m}^{2}$; (d) $1.5 \mathrm{~kg} / \mathrm{m}^{2}$.

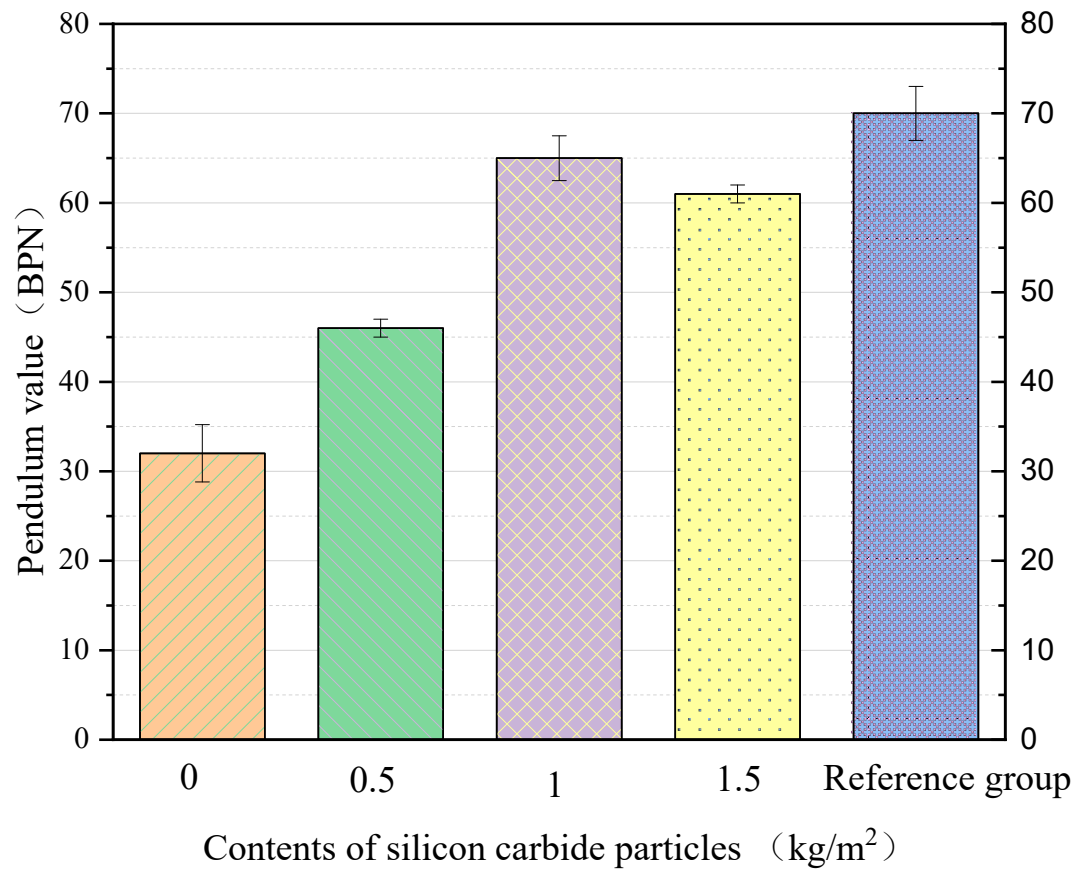

Figure 14. BPN contrast for the four kinds of surfaces and the uncoated surface.

Laying the coating can cause the antiskid performance of the asphalt concrete surface to decrease. As shown in Figure 14, the BPN of the coated pavement surface without added silicon carbide particles was nearly $54.3 \%$ less than that of the uncoated surface.

However, the spreading of silicon carbide particles can effectively improve the antiskid performance of the coating surface. As the content of silicon carbide particles increased, the BPN, an index to evaluate the antiskid performance, increased significantly and then decreased slightly. When the distribution amount was from 0 to $1 \mathrm{~kg} / \mathrm{m}^{2}$, the BPN of the road surface was approximately doubled from 32 to $65 \mathrm{BPN}$, far more than for a coated surface without silicon carbide particles and exceeding the specified BPN requirement of 45 . This is because the addition of silicon carbide particles changes the texture of the surface, as shown in Figure 13. 
The slight decrease in the BPN when the silicon carbide admixture increased from 1 to $1.5 \mathrm{~kg} / \mathrm{m}^{2}$ is attributable to the silicon carbide particles filling the concave part of the pavement surface, reducing the road's texture depth.

In summary, silicon carbide particles can be used to improve the antiskid performance of a CCCL. The optimal distribution amount is $1 \mathrm{~kg} / \mathrm{m}^{2}$, at which point the antiskid coefficient of the pavement surface substantially exceeds what is required for driving safely on an asphalt pavement (45 BPN).

\section{Conclusions}

In this work, we investigated a new strategy for a cool coating layer (CCL) with reflective and insulative properties that achieves the needed redirection of solar energy without being unduly expensive and without sacrificing skid resistance. This study contributes to reducing the temperature of asphalt pavements and further mitigating the problem of permafrost melting in the high-altitude western regions of China. Based on the results discussed above, the following conclusions can be drawn:

- A new device was developed to test the cooling effect of coatings. It has the following design features to ensure that the test results are more scientific and accurate: it can control environmental conditions, such as temperature and humidity; simulate natural light as realistically as possible, including parallel light design, light radiation intensity, and so forth; the sample is insulated. In addition, a scientific testing method was proposed to ensure that the testing process is carried out in a scientific and orderly manner.

- The reflection function is the fundamental factor affecting the temperature when asphalt pavement reaches the thermal equilibrium state. Coatings containing reflective functional materials have a better cooling effect than those that do not contain reflective functional materials. The cooling effects of RCCL and CCCL were higher than those of ICCL, which were 5.06 and $7.07^{\circ} \mathrm{C}$, respectively. The heat insulation function is a key factor for improving the cooling effect. Therefore, a composite cool coating layer (CCCL) was proposed, and it can improve the reflection of sunlight and inhibit the downward flow of energy. The CCCL can reach a cooling effect of $11.21^{\circ} \mathrm{C}$.

- CCCL is composed of the following materials: polyurethane resin, rutile $\mathrm{TiO}_{2}$ of $18 \%$ (VC), hollow glass microsphere of $12 \%$ (VC), and copper chromite black spinel of $0.7 \%$ (mass fraction).

- Laying the coating can cause the antiskid performance of the asphalt concrete surface to decrease. However, the spreading of silicon carbide particles can effectively improve the antiskid performance of the coating surface. The optimal distribution amount was found to be $1 \mathrm{~kg} / \mathrm{m}^{2}$, at which point the antiskid coefficient of the pavement surface substantially exceeds what is required for driving safely on asphalt pavement (45 BPN).

As part of future developments of this work, the effects of repeated illumination on the optical properties of the coatings should be further investigated to verify their degradation. In addition, outdoor experimental roads should be established and compared with laboratory test results to analyze the practical application of coatings. Finally, it is recommended to establish a finite element model and perform thermal calculations to quantify the amount of energy savings.

Author Contributions: Conceptualization, K.H. and Y.C.; methodology, K.H.; software, K.H.; validation, K.H., Y.C., and Y.D.; formal analysis, K.H.; investigation, C.Y.; resources, K.H.; data curation, C.Y.; writing—original draft preparation, K.H.; writing—review and editing, Y.C.; supervision, Y.C.; project administration, K.H.; funding acquisition, G.C. All authors have read and agreed to the published version of the manuscript. 
Funding: This work was financially supported by Innovative Funds Plan of Henan University of Technology (Grant No. 2020ZKCJ05), Science and Technology Planning Project of Henan Province of China (No. 192102310229), the Cultivation Plan for Youth Backbone Teachers of Institution of Higher Education by Henan Province (No. 2019GGJS086), the Cultivation Plan for Youth Backbone Teachers by Henan University of Technology. Key Science and Technology Research project of Henan provincial department of education (No. 21A580002) and the foundation for Distinguished Young Talents of Henan University of Technology (No. 2018QNJH09).

Institutional Review Board Statement: Not applicable.

Informed Consent Statement: Not applicable.

Data Availability Statement: The data presented in this study are available in article.

Conflicts of Interest: The authors declare no conflict of interest.

\section{References}

1. Zhang, Z.; Wu, Q.; Liu, Y.; Zhang, Z. Thermal accumulation mechanism of asphalt pavement in permafrost regions of the Qinghai-Tibet Plateau. Appl. Therm. Eng. 2018, 129, 345-353. [CrossRef]

2. Yu, Q.H.; Fan, K.; You, Y.H.; Guo, L. Comparative analysis of temperature variation characteristics of permafrost roadbeds with different widths. Cold Reg. Sci. Technol. 2015, 117, 12-18. [CrossRef]

3. Zhang, X.G.; Yan, L.E.; Qin, Y.H. Regulating solar absorptance for remedying thermal asymmetry of a roadway embankment. Int. J. Heat Mass Transf. 2018, 121, 64-71. [CrossRef]

4. Qin, W.M.; Wang, L.C.; Lin, A.W.; Zhang, M. Comparison of deterministic and data-driven models for solar radiation estimation in China. Renew. Sustain. Energy Rev. 2018, 81, 579-594. [CrossRef]

5. Guo, M.; Tan, Y. Interaction between asphalt and mineral fillers and its correlation to mastics' viscoelasticity. Int. J. Pavemrnt Eng. 2019, 22, 1-10. [CrossRef]

6. Hu, G.J.; Wu, X.D.; Zhao, L.; Li, R. An improved model for soil surface temperature from air temperature in permafrost regions of Qinghai-Xizang (Tibet) Plateau of China. Meteorol. Atmos. Phys. 2017, 129, 441-451. [CrossRef]

7. Qian, J.; Yu, Q.H.; Wu, Q.B.; You, Y.H. Analysis of asymmetric temperature fields for the duct-ventilated embankment of highway in permafrost regions. Cold Reg. Sci. Technol. 2016, 132, 1-6. [CrossRef]

8. Zhang, M.Y.; Zhang, X.Y.; Li, S.Y.; Wu, D.Y. Evaluating the cooling performance of crushed-rock interlayer embankments with unperforated and perforated ventilation ducts in permafrost regions. Energy 2015, 93, 874-881. [CrossRef]

9. Sun, B.X.; Yang, L.J.; Bai, W.H.; Liu, Q. Experimental investigation on porosity reduction of a coarsely crushed rock layer subject to vertically cyclic loading. Cold Reg. Sci. Technol. 2014, 104, 88-96. [CrossRef]

10. Bian, X.L.; He, P.; Wu, Q.B. Field test on ventilation characteristics of block stone embankments in Qinghai-Tibet Railway. Soil Mech. Found. Eng. 2014, 51, 234-241. [CrossRef]

11. Pruessner, L.; Phillips, M.; Farinotti, D.; Hoelzle, M. Near-surface ventilation as a key for modeling the thermal regime of coarse blocky rock glaciers. Permafr. Periglac. Process. 2018, 29, 152-163. [CrossRef]

12. Hou, Y.; Li, Q.; Zhang, C.; Lu, G. The State-of-the-Art Review on Applications of Intrusive Sensing, Image Processing Techniques, and Machine Learning Methods in Pavement Monitoring and Analysis. Engineering 2020. [CrossRef]

13. Guo, M.; Liu, H.; Jiao, Y.; Mo, L. Effect of WMA-RAP technology on pavement performance of asphalt mixture: A state-of-the-art review. J. Clean. Prod. 2020, 266, 121704. [CrossRef]

14. Qin, Y.H.; Zhang, J.M. A review on the cooling effect of duct-ventilated embankments in China. Cold Reg. Sci. Technol. 2013, 95, 1-10. [CrossRef]

15. Hou, Y.D.; Wu, Q.B.; Niu, F.J.; Liu, Y.Z. Thermal stabilization of duct-ventilated railway embankments in permafrost regions using ripped-rock revetment. Cold Reg. Sci. Technol. 2015, 120, 145-152.

16. Alekseev, A.G.; Khrustalev, L.N.; Konash, V.E. Use of low-rise building foundations on heat-insulated sand pads in permafrost regions. Soil Mech. Found. Eng. 2018, 55, 134-138. [CrossRef]

17. Zhu, Q.; Wang, W.; Wang, S.; Zhou, X. Unilateral heat-transfer asphalt pavement for permafrost protection. Cold Reg. Sci. Technol. 2012, 71, 129-138. [CrossRef]

18. Zhang, Y.N.; Wang, L.B.; Diefenderfer, B.K. Evaluation of moisture susceptibility of high-porosity ATPB drainage layer materials using modified dynamic modulus Test. J. Mater. Civ. Eng. 2016, 28, 04016091. [CrossRef]

19. Wang, X.W.; Gu, X.Y.; Jiang, J.W.; Deng, H.Y. Experimental analysis of skeleton strength of porous asphalt mixtures. Constr. Build. Mater. 2018, 171, 13-21. [CrossRef]

20. Zhang, J.; Cui, X.Z.; Li, L.; Huang, D. Sediment transport and pore clogging of a porous pavement under surface runoff. Road Mater. Pavement Des. 2017, 18, 240-248. [CrossRef]

21. Hu, K.; Chen, Y.; Naz, F.; Zeng, C. Separation studies of concrete and brick from construction and demolition waste. Waste Manag. 2019, 85, 396-404. [CrossRef] [PubMed]

22. Moriyoshi, A.; Jin, T.; Nakai, T.; Ishikawa, H. Construction and pavement properties after seven years in porous asphalt with long life. Constr. Build. Mater. 2014, 50, 401-413. [CrossRef] 
23. Imaninasab, R.; Bakhshi, B.; Shirini, B. Rutting performance of rubberized porous asphalt using Finite Element Method (FEM). Constr. Build. Mater. 2016, 106, 382-391. [CrossRef]

24. Du, Y.F.; Wang, S.Y.; Zhang, J. Cooling asphalt pavement by a highly oriented heat conduction structure. Energy Build. 2015, 102, 187-196.

25. Choi, W.; Kikumoto, H.; Ooka, R. New perspectives in thermal performance test: Cost-effective apparatus and extended data analysis. Energy Build. 2018, 180, 109-121. [CrossRef]

26. Cao, X.J.; Tang, B.M.; Luo, T.Y.; Guo, P. Preparation of fluorinated acrylate coating with high albedo and its cooling effect on asphalt mixture. Road Mater. Pavement Des. 2017, 18, 464-476. [CrossRef]

27. Qin, Y. A review on the development of cool pavements to mitigate urban heat island effect. Renew. Sustain. Energy Rev. 2015, 52, 445-459. [CrossRef]

28. Chen, J.; Wang, H.; Zhu, H. Analytical approach for evaluating temperature field of thermal modified asphalt pavement and urban heat island effect. Appl. Therm. Eng. 2017, 113, 739-748. [CrossRef]

29. Du, Y.F.; Han, Z.; Chen, J.Q.; Liu, W.Z. A novel strategy of inducing solar absorption and accelerating heat release for cooling asphalt pavement. Sol. Energy 2018, 159, 125-133.

30. Sha, A.M.; Liu, Z.Z.; Tang, K.; Li, P.Y. Solar heating reflective coating layer (SHRCL) to cool the asphalt pavement surface. Constr. Build. Mater. 2017, 139, 355-364. [CrossRef]

31. Friel, S.; Woodward, D. High friction surfacing systems using blends of natural aggregate and calcined bauxite. Coatings 2019, 9, 177.

32. Li, Q.J.; Zhan, Y.; Yang, G.; Wang, K.C.P. Pavement skid resistance as a function of pavement surface and aggregate texture properties. Int. J. Pavement Eng. 2020, 21, 1159-1169. [CrossRef]

33. Perez-Acebo, H.; Gonzalo-Orden, H.; Findley, D.J.; Roji, E. A skid resistance prediction model for an entire road network. Constr. Build. Mater. 2020, 262, 120041. [CrossRef]

34. Jiang, W.; Huang, Y.; Sha, A. A review of eco-friendly functional road materials. Constr. Build. Mater. 2018, 191, 1082-1092. [CrossRef]

35. Chen, Y.; Hu, K.; Cao, S. Thermal performance of novel multilayer cool coatings for asphalt pavements. Materials 2019, 12, 1903. [CrossRef] [PubMed]

36. Zheng, M.; Han, L.; Wang, F.; Mi, H. Comparison and analysis on heat reflective coating for asphalt pavement based on cooling effect and anti-skid performance. Constr. Build. Mater. 2015, 93, 1197-1205. [CrossRef] 